\title{
STUDI KOMPARATIF PENDANAAN PEMBANGUNAN DAERAH DENGAN PENERIMAAN UMUM DAERAH, OBLIGASI DAERAH, DAN PEMBAYARAN KETERSEDIAAN LAYANAN
}

\author{
Roby Aditiya \\ roby.aditiya@uin-alauddin.ac.id \\ Supriyadi \\ supriyadi@mail.ugm.ac.id
}

\begin{abstract}
The development of regional infrastructures is necessary to improve the service for the welfare of the people. In fact, not all local governments have a budget to fund the infrastructure development. This study compared the efficient funding source for regional infrastructure development between the funding from regional general acceptance with regional bonds and availability payment. This study refers to the case of the development of Wates Regional General Hospital (RSUD Wates) of Kulon Progo Regency. This study uses an interpretive paradigm with a descriptive qualitative research approach. The results show that funding with regional bonds is more efficient than funding with availability payment and funding from general regional acceptance. The regional bond scheme provides a funding efficiency of IDR501.71 billion compared to using regional general acceptance, while alternative funding for availability payment provides an efficiency of IDR430.69 billion compared to using sources from regional general acceptance. The difference shows that regional bonds are more efficient at IDR 71.02 billion compared to alternative funding for availability payment.
\end{abstract}

Keywords: regional bonds, availability payment, regional funding.

\section{PENDAHULUAN}

Era otonomi daerah dan desentralisasi fiskal menuntut kemandirian daerah untuk dapat melakukan tugas dan tanggungjawab dalam memberikan pelayanan yang terbaik untuk meningkatkan kesejahteraan bagi masyarakat (Halim, 2014). Oleh karena itu, pemerintah daerah dituntut untuk dapat melakukan pembangunan diberbagai sektor. Salah satunya ialah pembangunan infrastruktur yang memadai. Pembangunan infrastruktur diyakini mampu memberikan multiplier effect dalam menggerakkan sektor rill, menyerap tenaga kerja, meningkatkan investasi, meningkatkan konsumsi masyarakat dan pemerintah, memicu kegiatan produksi serta meningkatkan perekonomian (Esfahani \& Ramı'rez, 2003; Daroedono, 2004; Sahoo \& Dash, 2009; Palei, 2015). 
Hanya saja, pembangunan infrastruktur daerah membutuhkan dana yang besar yang berimplikasi terhadap ketidakmampuan ruang fiskal pemerintah daerah untuk memenuhi kebutuhan pembangunan infrastruktur tersebut. Oleh karena itu, pemerintah daerah masih menggantungkan pendanaannya pada penerimaan umum daerah berupa dana perimbangan yang dikucurkan oleh pemerintah pusat baik dalam bentuk dana bagi hasil, dana alokasi umum, maupun dana alokasi khusus (Hamid, 2003; Kusumadewi \& Rahman, 2007; Dewi \& Kaluge, 2011; Inayati \& Setiawan, 2017).

Adanya ketimpangan antara kebutuhan pembangunan dan kemampuan pendanaan tersebut, mengharuskan pemerintah daerah mencari alternatif pendanaan lainnya. Di Indonesia, beberapa kebijakan telah dikeluarkan oleh pemerintah pusat untuk memberikan ruang kepada pemerinah daerah dalam mencari alternatif pendanaan pembangunan infrastruktur daerah. Alternatif pendanaan tersebut dapat dilakukan dengan skema pinjaman daerah maupun dengan skema kerjasama pemerintah daerah dan badan usaha (KPDBU) atau yang biasa disebut public private partnership (PPP) (Elmi, 2005; Djunedi, 2008; Kurniawan, Pudjianto, \& Wicaksono, 2009; Fatimah, 2011; Ambarwati, 2016).

Ketentuan mengenai pinjaman daerah diatur dalam Peraturan Pemerintah (PP) Nomor 30 Tahun 2011 tentang Pinjaman Daerah.. Salah satu skema pinjaman daerah dalam PP tersebut yang dewasa ini menarik perhatian pemerintah daerah di Indonesia ialah obligasi daerah. Beberapa pemerintah provinsi di Indonesia bahkan telah melakukan kajian persiapan penerbitan obligasi daerah (Dewi \& Kaluge, 2011). Obligasi daerah diyakini dapat mempermudah dalam memperoleh dana yang besar untuk pembangunan infrastruktur, juga dapat menjadi solusi dan memberikan manfaat bagi masyarakat, investor dan pelaku pasar modal (Elmi, 2005). Dengan obligasi daerah, pemerintah daerah diharapkan dapat melakukan akselesari pembangunan tanpa bergantung semata-mata dari transfer pemerintah pusat (Surachman \& Setiawan, 2016; Dewi \& Kaluge, 2011).

Selain obligasi daerah, terdapat alternatif pendanaan pembangunan daerah berupa pembayaran ketersediaan layanan. Alternatif ini merupakan salah satu bentuk dari skema 
Kerjasama Pemerintah Daerah dengan Badan Usaha (KPDBU) (Sharma \& Cui, 2012). Konsep KPDBU banyak diterapkan oleh pemerintah daerah dalam rangka mengajak investor swasta, domestik maupun asing untuk bekerjasama dalam penyediaan infrastruktur (Sharma \& Cui, 2012; Djunedi, 2008; Masitoh, 2014; Grout, 2005). Mekanisme pendanaan dengan skema pembayaran ketersediaan layanan telah diatur dalam Peraturan Menteri Dalam Negeri (Permendagri) No. 96 Tahun 2016 tentang Pembayaran Ketersediaan Layanan dalam Rangka Kerjasama Pemerintah Daerah dengan Badan Usaha dalam Penyediaan Infrastruktur di Daerah.

Kedua alternatif pendanaan tersebut merupakan alternatif pendanaan pembangunan infrastruktur daerah yang lebih mutakhir dibandingkan menggunakan penerimaan umum daerah dalam anggaran pendapatan dan belanja daerah (APBD). Oleh karena itu, menjadi menarik untuk dikaji lebih mendalam terkait tingkat efisiensinya dibandingkan menggunakan penerimaan umum daerah dalam anggaran pendapatan dan belanja daerah (APBD).

Studi komparatif alternatif pendanaan pembangunan infrastruktur daerah ini mengacu pengembangan Rumah Sakit Umum Daerah (RSUD) Wates Kabupaten Kulon Progo. Pemilihan kabupaten tersebut sebagai objek penelitian dengan pertimbangan bahwa Kabupaten Kulon Progo merupakan salah satu kabupaten di Indonesia yang sebagian besar belanjanya masih berfokus pada belanja operasi dibanding dengan belanja modal. Rata-rata belanja modal Pemerintah Kabupaten Kulon Progo dalam laporan realisasi anggaran (LRA) dari tahun 2013 hingga tahun 2016 hanya sebesar 16,58\% dari total belanja daerah. Kondisi ini mengindikasikan bahwa Pemerintah Kabupaten Kulon Progo memiliki kesulitan untuk mengalokasikan anggaran yang memadai untuk pembangunan infrastruktur daerah yang notabene membutuhkan dana yang besar.

Kesulitan pendanaan tersebut kontradiktif dengan status Kabupaten Kulon Progo yang akan menjadi salah satu pintu masuk di kawasan Daerah Istimewah Yogyakarta (DIY). Hal ini disebabkan oleh adanya Mega Proyek Pembangunan Bandara DIY di Kulon Progo. Adanya bandara tersebut tentu menuntut respon dari pemerintah setempat untuk 
menyediakan fasilitas-fasilitas umum yang dapat memberikan efek pengganda dari adanya bandara tersebut guna mendorong peningkatan aktifitas ekonomi daerah.

Salah satu fasilitas pendukung yang sedang dibangun oleh Pemerintah Kabupaten Kulon Progo ialah perluasan bangunan dan fasilitas Rumah Sakit Umum Daerah (RSUD) Wates Kabupaten Kulon Progo. Perluasan dan peningkatan fasilitas tersebut sebagai upaya untuk mentransformasi RSUD Wates menjadi RSUD Pendidikan Kabupaten Kulon Progo yang berkelas internasional. Total anggaran yang dibutuhkan sebagaimana yang tercantum dalam Studi Kelayakan Perluasan Bangunan dan Fasilitas RSUD Wates Kabupaten Kulon Progo ialah sebesar Rp485,69 milyar. Dana sebesar itu belum mampu disediakan oleh Pemerintah Kabupaten Kulon Progo dalam satu atau dua periode anggaran jika menggunakan penerimaan umum daerah.

Atas dasar adanya ketimpangan antara kebutuhan dana dengan kemampuan keuangan daerah maka perlu dilakukan studi komparatif alternatif pendanaan pembangunan infrastruktur daerah yang lebih mutakhir. Penelitian ini diharapkan mampu menunjukkan tingkat efisiensi pendanaan pembangunan infrastruktur daerah dengan obligasi daerah dan pembayaran ketersediaan layanan dibandingkan dengan pendanaan dari penerimaan umum daerah. Selain itu hasil penelitian diharapkan menjadi pertimbangan Pemerintah Kabupaten Kulon Progo dan pemerintah lainnya untuk menggunakan alternatif pendanaan obligasi daerah atau pembayaran ketersediaan layanan dalam proyek pembangunan infrastruktur daerah.

\section{LANDASAN TEORI}

\section{Obligasi Daerah}

Salah satu jenis pinjaman daerah yang selama ini diharapakan dapat dimanfaatkan oleh pemerintah daerah untuk menghimpun dana dari masyarakat ialah pinjaman daerah dengan skema obligasi daerah (Ambarwati, 2016; Dewi \& Kaluge, 2011; Elmi, 2005; Purnomo, 2015). Obligasi daerah didefinisikan sebagai surat berharga yang menunjukkan 
bahwa penerbit obligasi (pemerintah daerah) menjamin sejumlah dana kepada masyarakat (pembeli obligasi) dan memiliki kewajiban untuk membayar secara berkala (pokok, bunga, dan denda) pada waktu yang telah ditentukan (Darmadji \& Fakhruddin, 2006; Sitorus, 2015; Purnomo, 2015). Obligasi daerah merupakan salah satu skema pembiayaan yang cukup populer di negara maju dan berkembang (Hamid, 2003; Elmi, 2005; Purnomo, 2015). Hal ini karena pembiayaan dengan obligasi daerah selain mempermudah dalam memperoleh dana pembangunan infrastruktur, juga dapat menjadi solusi dan memberikan manfaat bagi masyarakat, investor dan pelaku pasar modal ( (Hamid, 2003; Elmi, 2005).

Beberapa tahap harus dilakukan dan dilalui pemerintah daerah sebelum menerbitkan obligasi daerah di pasar modal. Tahap-tahap tersebut meliputi persiapan di daerah, persetujuan Menteri Keuangan, tahap pra-registrasi dan registrasi, hingga tahap penawaran umum (DJPK, 2007).

1. Persiapan di Daerah

Pemerintah daerah dalam upaya melakukan penerbitan obligasi daerah perlu membentuk sebuah tim persiapan penerbitan obligasi daerah. Tim persiapan bertanggung jawab untuk menyiapkan rencana kegiatan investasi yang akan dibiayai. Dalam ketentuan perubahan pasal 8 ayat (2) dalam PMK 180/PMK.07 Tahun 2015 setidaknya telah disebutkan enam tahap yang harus dilakukan pemerintah daerah dalam melakukan persiapan penerbitan obligasi daerah.

a. Pemerintah daerah menentukan kegiatan yang akan didanai dengan obligasi daerah.

b. Membuat Kerangka Acuan Kegiatan.

c. Langkah selanjutnya adalah membuat perhitungan batas kumulatif pinjaman. Batas kumulatif pinjaman daerah yaitu jumlah sisa pinjaman daerah ditambah jumlah pinjaman yang akan ditarik tidak melebihi $75 \%$ dari jumlah penerimaan umum APBD tahun sebelumnya.

d. Selanjutnya menghitung rasio kemampuan keuangan daerah yang dikenal dengan istilah debt service coverage ratio (DSCR). DSCR menjadi penting untuk dijadikan dasar dalam 
menentukan apakah pinjaman yang diambil nantinya akan menyulitkan kondisi keuangan entitas atau tidak (Noor, 2009). Rumus yang dapat digunakan dalam menghitung DSCR tercantum dalam penjelasan PP No. 30 Tahun 2011 sebagai berikut.

$D S C R=\frac{\{P A D+(D B H-D B H D R)+D A U\}-B W}{\text { Angsuran Pokok Pinjaman }+ \text { Bunga }+ \text { Biaya Lain }} \geq 2,5$

e. Selanjutnya pemerintah daerah mengajukan permohonan persetujuan prinsip kepada Dewan Perwakilan Rakyat Daerah (DPRD). Setidaknya ada tiga perihal yang harus tertuang dalam surat persetujuan prinsip DPRD yaitu: (1) nilai bersih maksimal obligasi daerah yang akan diterbitkan pada saat penetapan APBD, (2) kesediaan pembayaran pokok dan bunga sebagai akibat penerbitan obligasi daerah, dan (3) kesediaan pembayaran segala biaya yang timbul dari penerbitan obligasi daerah.

f. Terakhir dalam tahap persiapan ialah membentuk struktur organisasi, perangkat kerja, dan sumber daya manusia unit pengelola obligasi daerah.

2. Pesetujuan Menteri Keuangan

Langkah selanjutnya ialah pemerintah daerah mengajukan usul penerbitan obligasi daerah untuk mendapatkan persetujuan kepada Menteri Keuangan dalam hal ini Direktur Jenderal Perimbangan Keuangan (DJPK, 2007). Untuk memberikan persetujuan, setidaknya Kementerian Keuangan melakukan penilaian meliputi penilaian administrasi dan penilaian keuangan. Surat usulan penerbitan obligasi daerah harus dilengkapi dengan dokumendokumen sebagai berikut.

a. Kerangka Acuan Kegiatan.

b. Laporan keuangan pemerintah daerah selama 3 (tiga) tahun terakhir.

c. Peraturan daerah mengenai APBD tahun berkenaan.

d. Perhitungan jumlah kumulatif pinjaman pemerintah daerah dan defisit APBD.

e. Perhitungan rasio kemampuan keuangan daerah untuk mengembalikan pinjaman atau debt service coverage ratio (DSCR).

f. Surat persetujuan prinsip dari Dewan Perwakilan Rakyat Daerah. 
g. Struktur organisasi, perangkat kerja, dan sumber daya manusia unit pengelola obligasi daerah.

3. Pra-registrasi dan Registrasi

Pada tahap pra-regisrasi dan registrasi sebenarnya sudah mulai memasuki skema penerbitan obligasi di pasar modal. Tahap pra-registrasi meliputi langkah-langkah yang harus ditempuh sebelum mengajukan pernyataan pendaftaran ke Otoroitas Jasa Keuangan (OJK) yang diantaranya menunjuk profesi-profesi penunjang, melakukan uji tuntas (due diligence), pemeringkatan efek, persiapan pendaftaran, pembuatan janji-janji terkait dan penetapan struktur obligasi daerah (DJPK, 2007). Jika persyaratan telah lengkap dan memenuhi kriteria maka OJK akan mengeluarkan pernyataan efektif dalam rangka penawaran umum obligasi daerah.

\section{Penawaran Umum}

Tahap selanjutnya adalah penawaran umum dan pencatatan. Jangka waktu yang dibutuhkan selama proses penawaran umum, terhitung sejak pernyataan pendaftaran dinyatakan efektif oleh OJK hingga obligasi daerah dibeli oleh investor dan dicatatkan di bursa efek adalah kurang lebih 10 hari kerja (DJPK, 2007).

\section{Pembayaran Ketersediaan Layanan (Availability payment)}

Kerjasama pemerintah daerah dengan badan usaha (KPDBU) atau public private partnership (PPP) merupakan alternatif lain yang dapat dimanfaatkan oleh pemerintah daerah untuk mendapatkan bantuan dana dalam pembangunan infrastruktur. (Djunedi, 2008; Kurniawan, Pudjianto, \& Wicaksono, 2009; Masitoh, 2014). Salah satu skema pendanaan dalam KPDBU ialah skema Pembayaran Ketersediaan Layanan (Availability Payment) (Sharma \& Cui, 2012). Skema pembayaran ketersediaan layanan menjadi salah satu skema pendanaan yang ditawarkan oleh pemerintah pusat melalui Peraturan Pemerintah (PP) No. 38 Tahun 2015 tentang Kerjasama Pemerintah dengan Badan Usaha (KPBU) dalam Penyediaan Infrastruktur. Dalam PP tersebut menyatakan bahwa 
pembayaran ketersediaan layanan adalah pembayaran secara berkala oleh Menteri/Kepala Lembaga/Kepala Daerah kepada Badan Usaha Pelaksana atas tersedianya layanan infrastruktur yang sesuai dengan kualitas dan/atau kriteria sebagaimana ditentukan dalam perjanjian KPBU. Skema ini memiliki tujuan untuk (1) memastikan ketersediaan layanan yang berkualitas kepada masyarakat secara berkesinambungan dan (2) mengoptimalkan nilai guna dari APBD (time value of money) dalam penyediaan layanan.

Tahap pelaksanaan KPBU dengan skema pembayaran ketersediaan layanan dimulai dengan perencanaan pembayaran ketersediaan layanan, penyiapan pembayaran ketersediaan layanan, dan transaksi pembayaran ketersediaan layanan.

1. Tahap Perencanaan Pembayaran ketersediaan layanan

Tahap perencanaan dimaksudkan untuk memperoleh informasi mengenai kebutuhan penyediaan infrastruktur yang dapat dikerjasamakan dengan badan usaha dan untuk mendukung koordinasi perencanaan dan pengembangan rencana pembayaran ketersediaan layanan serta melakukan keterbukaan informasi kepada masyarkat mengenai rencana pembayaran ketersediaan layanan. Tahap perencanaan pembayaran ketersediaan layanan dijelaskan dalam pasal 7 hingga 13 Permendagri No. 96 Tahun 2016 yang terdiri dari beberapa kegiatan yaitu sebagai berikut.

a. Pemerintah daerah melakukan penyusunan rencana anggaran dana pembayaran ketersediaan layanan sesuai dengan peraturan perundang-undangan dengan memperhatikan setiap tahap pelaksanaan KPBU dengan skema pembayaran ketersediaan layanan.

b. Langkah kedua ialah dentifikasi dan penetapan pembayaran ketersediaan layanan. Dalam rangka melakukan identifikasi, maka pemerintah daerah menyusun studi pendahuluan dan melakukan konsultasi publik.

c. Selanjutnya pengambilan keputusan apakah akan melanjutkan atau menghentikan pembangunan skema pembayaran ketersediaan layanan.

2. Tahap Penyiapan 
Ketika memutuskan untuk melanjutkan pembangunan infrastruktur dengan skema pembayaran ketersediaan layanan, maka langkah selanjutnya adalah penyiapan KPBU dengan skema pembayaran ketersediaan layanan. Langkah-langkah tersebut telah tertuang dalam Permendagri No. 96 Tahun 2016 pada pasal 14 hingga pasal 22 sebagai berikut.

a. Langkah pertama adalah pra studi kelayakan investasi. Kajian ini terdiri dari berbagai aspek antara lain: (1) kajian hukum dan kelembangaan, (2) kajian teknis, (3) kajian ekonomi dan sosial, (4) kajian lingkungan dan sosial, (5) kajian bentuk kerjasama dalam penyediaan infrastruktur, (6) kajian risiko, (7) kajian kebutuhan dukungan Pemerintah dan/atau Jaminan Pemerintah, serta (8) kajian mengenai hal-hal yang perlu ditindaklanjuti.

b. Selanjutnya melakukan konsultasi publik dan penjajakan minat pasar (market sounding).

c. Untuk melancarkan proses pembayaran ketersediaan layanan, maka pemerintah daerah dapat mengajukan usulan terhadap dukungan Pemerintah dalam pembayaran ketersediaan layanan.

\section{Tahap Transaksi}

Setelah seluruh syarat-syarat terpenuhi dari tahap perencanaan hingga penyiapan, maka selanjutnya adalah tahap transaksi. Dalam Permendagri No. 96 Tahun 2016, ketentuan mengenai tahap transaksi dibahas dari pasal 23 hingga pasal 34. Setidaknya terdapat 3 kegiatan dalam tahap transaksi ini, yaitu:

a. pengadaan Badan Usaha Pelaksana yang mencakup persiapan dan pelaksanaan pengadaan Badan Usaha Pelaksana.

b. Penandatangan pernjanjian KPBU dengan skema pembayaran ketersediaan layanan.

c. Pemenuhan pendanaan (financial close).

\section{METODE PENELITIAN}

Penelitian ini menggunakan paradigma interpretif dengan pendekatan penelitian kualitatif deskriptif. Data penelitian yang dikumpulkan dalam penelitian ini adalah data 
sekunder berupa Rencana Pengembangan RSUD Wates Kabupaten Kulon Progo, Laporan Keuangan Kabupaten Kulon Progo, serta dokumen pendukung lainnya yang kemudian dianalisis dan diinterpretasikan sesuai kebutuhan penelitian.

Analisis data dilakukan dengan dua tahap utama. Analisis pertama berfokus pada kajian mengenai simulasi investasi pada proyek pengembangan infrastruktur RSUD Wates Kabupaten Kulon Progo dengan skema obligasi daerah dan pembayaran ketersediaan layanan. Beberapa hal yang harus dianalisis antara lain (1) Batas Maksimum Pinjaman Daerah, (2) Debt Service Coverage Ratio (DSCR), dan Menghitung Total Avilability Payment. Perhitungan simulasi obligasi daerah mengacu pada Peraturan Menteri Keuangan Nomor 180/PMK.07 Tahun 2015 tentang Perubahan atas Peraturan Menteri Keuangan Nomor 111/PMK.07 Tahun 2012 tentang Tata Cara Penerbitan dan Pertanggungjawaban Obligasi Daerah, serta mengacu pada Panduan Penerbitan Obligasi Daerah yang dikeluarkan oleh Direktorat Jenderal Perimbangan Keuangan, Departemen Keuangan Republik Indonesia. Perhitungan simulasi Pembayaran Ketersediaan Layanan mengacu pada Peraturan Menteri Perencanaan Pembangunan Nasional atau Kepala Badan Perencanaan Pembangunan Nasional Nomot 4 Tahun 2015 tentang Tata Cara Pelaksanaan Kerjasama Pemerintah Dengan Badan Usaha Dalam Penyediaan Infrastruktur, serta mengacu pada perhitungan pembayaran ketersediaan layanan dalam Laporan Akhir Kajian Awal Pra Studi Kelayakan KPBU RSUD Krian Kabupaten Sidoarjo.

Analisis kedua yaitu analisis komparatif alternatif pendanaan antara obligasi daerah dan pembayaran ketersediaan layanan dengan pendanaan dari penerimaan umum daerah. Pendekatan yang digunakan dalam analisis komparatif alternatif pendanaan ialah time value of money dengan melihat present value masing-masing alternatif pendanaan tersebut. Angka-angka proyeksi dalam penelitian ini dihitung menggunakan metode trend linear kuadrat terkecil (least square). 


\section{HASIL PENELITIAN DAN PEMBAHASAN}

\section{Kebutuhan Dana Pengembangan RSUD Wates}

Anggaran yang dibutuhkan untuk pengembangan RSUD Wates Kabupaten Kulon Progo tersebut sebesar Rp272,18 milyar untuk fisik bangunan dan Rp213,51 milyar untuk pengadaan alat-alat kesehatan. Dengan demikian total anggaran yang dibutuhkan untuk pengembangan RSUD tersebut sebesar Rp485,69 milyar.

\section{Simulasi Obligasi Daerah}

Simulasi yang disusun berfokus kepada aspek kemampuan keuangan Kabupaten Kulon Progo untuk menerbitkan obligasi daerah. Dalam Studi Kelayakan Pengembangan RSUD Wates, telah dilakukan analisis ekonomi dan keuangan dengan hasil net present value (NPV) sebesar Rp80,98 milyar, internal rate of return (IRR) sebesar 9,16\%, payback period (PBC) selama 20 Tahun 8 Bulan, dan profitability index $(\mathrm{PI})$ sebesar 1,150. Berikut ini langkah-langkah yang dilakukan untuk menyususn simulasi penerbitan obligasi daerah.

1. Menghitung Batas Maksimum Pinjaman Daerah

Sebelum menentukan batas maksimum pinjaman daerah, maka perlu dilakukan perhitungan penerimaan umum daerah pada tahun sebelum mengajukan pendanaan dengan obligasi daerah. Penerimaan umum daerah dihitung dengan rumus sebagai berikut.

$$
\mathrm{PU}=\mathrm{PD}-(\mathrm{DAK}+\mathrm{DD}+\mathrm{DP}+\mathrm{L})
$$

Dimana:

PU = Penerimaan Umum

$\mathrm{PD} \quad=$ Total Penerimaan Daerah

DAK = Dana Alokasi Khusus

$\mathrm{DD} \quad=$ Dana Darurat

DP $=$ Pembayaran Pokok Pinjaman

L $\quad=$ Pendapatan Pendanaan Tertentu

Tahun dasar obligasi daerah dalam penelitian ini diasumsikan mulai tahun 2017. Oleh karena itu, penerimaan umum APBD akan menggunakan data-data pada tahun anggaran 2016.

Tabel 1 Penerimaan Umum Daerah Tahun 2016 (dalam milyar rupiah) 


\begin{tabular}{|c|c|}
\hline Keterangan & $\mathbf{R p}$ \\
\hline Total Penerimaan Daerah 2016 & $1.358,07$ \\
\hline \multicolumn{2}{|l|}{ Pengurangan: } \\
\hline 1 Dana Alokasi Khusus & 212,67 \\
\hline Dana Darurat & - \\
\hline Pembayaran Pokok Pinjaman Sebelumnya & - \\
\hline Pendapatan Pendanaan Tertentu: & \\
\hline Bagian Pendapatan sebagai Transfer Bagi Hasil & 9,81 \\
\hline Bagian Pendapatan yang Ditransfer ke Desa & 135,04 \\
\hline Pendapatan telah Ditentukan Peruntukannya & 27,65 \\
\hline Pendapatan Dana Penyesuaian & 99,74 \\
\hline Penerimaan Umum Tahun 2016 & 873,16 \\
\hline
\end{tabular}

Total penerimaan umum APBD Kabupaten Kulon Progo Tahun Anggaran 2016 ialah sebesar Rp873,16 milyar. Dengan demikian, maka batas maksimum pinjaman Kabupaten Kulon Progo berdasarkan penerimaan umum tersebut sebagai berikut.

BMPD $=(75 \% \times$ PU $)-$ Pinjaman Sebelumnya

$\mathrm{BMPD}=(75 \% \times \operatorname{Rp} 873,16 \mathrm{M})-\operatorname{Rp} 5 \mathrm{M}$

$\mathrm{BMPD}=\mathrm{Rp} 654,87 \mathrm{M}-\mathrm{Rp} 5 \mathrm{M}$

BMPD = Rp649,87 M

Pemerintah Kabupaten Kulon Progo sebelumnya telah memiliki pinjaman sebesar Rp5 milyar dari Bank Pembangunan Daerah (BPD) DIY. Dengan demikian batas maksimum pinjaman yang boleh ditarik oleh Pemerintah Kabupaten Kulon Progo yaitu sebesar Rp649,87 milyar. Berdasarkan perhitungan batas maksimum pinjaman daerah, maka Pemerintah Kabupaten Kulon Progo memenuhi syarat untuk melakukan pinjaman daerah dengan skema obligasi daerah sebesar Rp485,69 milyar.

2. Menghitung Debt Coverage Service Ratio

Debt Coverage Service Ratio (DSCR) menunjukkan kemampuan keuangan daerah untuk melakukan pengembalian pinjaman selama periode pinjaman. Nilai DSCR pemerintah daerah untuk dianggap layak melakukan pinjaman ialah di atas 2,5. 
Perhitungan DSCR ini membutuhkan beberapa asumsi dan data-data pendukung. Berikut ini asumsi-asumsi yang digunakan untuk menghitung DSCR dalam konteks penerbitan obligasi daerah oleh Pemerintah Kabupaten Kulon Progo.

a. Obligasi daerah Pemerintah Kabupaten Kulon Progo diterbitkan pada tahun 2017 dengan bunga $7,17 \%$. Bunga $7,17 \%$ dianggap cukup bersaing apabila dibandingkan dengan beberapa alternatif lainnya dalam investasi keuangan pada tahun 2017. Misalnya ratarata imbal hasil dari Obligasi Negara Ritel (ORI) pada tahun 2017 diprediksi berkisar antara 7\% sampai 7,50\% (www.infovesta.com). Sementara itu, suku bunga deposito pada tahun 2017 diperkirakan berada pada kisaran 7,02\% (m.kontan.co.id). Jika berkaca juga dari pengalaman Pemerintah Kulon Progo yang sebelumnya telah melakukan pinjaman pada BPD DIY dengan suku bunga 11,5\%, maka suku bunga 7,17\% dianggap berada pada batas aman.

b. Obligasi daerah Pemerintah Kabupaten Kulon Progo diasumsikan dengan tenor 10 tahun. Dengan demikian, jika obligasi daerah dimulai pada tahun 2017, maka akan jatuh tempo pada tahun 2026. Pemilihan jangka waktu 10 tahun agar Pemerintah Kabupaten Kulon Progo memiliki waktu yang cukup untuk mengumpulkan dana untuk pembayaran pokok pinjaman serta mengurangi sensitifitas dengan inflasi.

c. Bunga obligasi daerah dibayarkan setiap tahun dengan nilai tetap, sementara untuk pokok obligasi daerah akan dibayarkan pada saat jatuh tempo yaitu di tahun 2026. Agar pembayaran pokok obligasi tidak memberatkan APBD pada saat jatuh tempo, maka pemerintah akan membentuk dana cadangan yang disimpan khusus untuk pembayaran pokok obligasi di masa mendatang. Pembentukan dana cadangan akan dimulai pada saat aset yang dibangun mulai beroperasi dengan baik. Untuk menentukan berapa dana yang harus dicadangkan setiap tahunnya, maka akan dilakukan perhitungan nilai anuitas majemuk.

d. Masa konstruksi dengan sumber pendanaan dari obligasi daerah diyakini akan lebih cepat satu tahun dibandingkan dengan menggunakan dana dari penerimaan umum 
daerah. Dengan demikian, masa konstruksi menjadi hanya 2 tahun dari 4 tahun pada rencana pembangunan dalam dokumen Pemerintah Kabupaten Kulon Progo. Pertimbangan tersebut karena dana untuk kebutuhan pembangunan infrastruktur akan tersedia lebih cepat ketika pendanaannya bersumber dari obligasi daerah dibandingkan ketika bersumber dari penerimaan umum di APBD.

e. Belanja wajib yang digunakan dalam perhitungan DSCR ialah belanja pegawai ditambah dengan transfer ke desa.

f. Nilai dasar dalam perhitungan proyeksi DSCR pada tahun 2013 hingga 2016 menggunakana data dalam Laporan Realisasi APBD Kabupaten Kulon Progo tahun anggaran 2013 hingga 2016. Sementara nilai dalam tahun 2017 menggunakan nilai dalam APBD Kabupaten Kulon Progo tahun anggaran 2017 dan nilai untuk tahun 2018 hingga 2026 menggunakan angka proyeksi yang diperoleh dari perhitungan metode trend linear kuadrat terkecil (least square).

g. Biaya lain-lain diasumsikan Rp0

Hasil perhitungan proyeksi DSCR selama perode obligasi yaitu tahun 2017 hingga 2026 dapat dilihat pada Tabel 2. Syarat pemerintah daerah agar dapat melakukan pinjaman daerah dengan skema obligasi daerah ialah harus memiliki nilai DSCR minimal 2,5. Berdasarkan hasil perhitungan DSCR, maka Pemerintah Kabupaten Kulon Progo memiliki kemampuan dimasa depan untuk membayar pinjaman obligasi daerah yang ditarik dari publik sebesar Rp485,69 milyar.

\begin{tabular}{cc} 
Tabel 2 Hasil Perhitungan DSCR \\
\hline Tahun & DSCR \\
\hline 2017 & 6,68 \\
\hline 2018 & 5,51 \\
\hline 2019 & 5,63 \\
\hline 2020 & 5,75 \\
\hline 2021 & 6,08 \\
\hline 2022 & 6,31 \\
\hline 2023 & 6,46 \\
\hline 2024 & 6,61 \\
\hline 2025 & 6,76 \\
\hline
\end{tabular}




\begin{tabular}{cc}
\hline Tahun & DSCR \\
\hline 2026 & 6,91 \\
\hline
\end{tabular}

\section{Simulasi Pembayaran ketersediaan layanan}

Simulasi yang akan disusun berfokus pada aspek keuangan atau besaran pembayaran ketersediaan layanan setiap tahunnya yang akan dibayarkan oleh Pemerintah Kabupaten Kulon Progo selama masa konsesi KPBU. Sebelum menyusun simulasi pendanaan dengan skema pembayaran ketersediaan layanan untuk pengembangan RSUD Wates Kabupaten Kulon Progo, maka terlebih dahulu ditentukan asumsi-asumsi yang akan digunakan dalam simulasi tersebut.

1. KPDBU dengan skema pembayaran ketersediaan layanan akan mulai dilakukan pada tahun 2017 dengan jangka waktu pembayaran ketersediaan layanan yaitu 10 tahun. Pada tahun 2017 akan dimulai kegiatan kontruksi. Jangka waktu kontruksi dengan skema pembayaran ketersediaan layanan diyakini selesai dalam 2 tahun. Jangka waktu 2 tahun ditentukan dengan pertimbangan bahwa badan usaha yang memenangkan lelang merupakan badan usaha yang memiliki kemampuan finansial untuk menutupi kebutuhan pembangunan infrastruktur tersebut. Selain itu, dengan skema pembayaran ketersediaan layanan maka badan usaha akan termotivasi untuk segera menyelesaikan pembangunan infrastruktur agar pembayaran atas ketersediaan layanan dapat segera dilakukan. Dengan demikian, layanan akan tersedia pada tahun 2019 sehingga pembayaran ketersediaan layanan juga akan dimulai pada tahun 2019 selama 10 tahun dan akan berakhir pada tahun 2028 .

2. Capital structure untuk pembangunan diperbolehkan $30 \%$ dari modal sendiri dan $70 \%$ dari pinjaman.

3. Pinjaman yang ditarik badan usaha untuk membantu modal sendiri diasumsikan selama 7 tahun dengan bunga pinjaman sebesar 10,35\% per tahun. Bunga pinjaman tersebut diambil dari rata-rata bunga pinjaman korporasi pada akhir tahun 2016 di Bank Rakyat Indonesia, Bank Negara Indonesia, Bank Mandiri, Bank Tabungan Negara, dan Bank 
Central Asia (www.bi.go.id). Pinjaman akan dimulai pada tahun 2018 dengan pertimbangan bahwa dana untuk konstruksi pada tahun 2017 masih akan ditutupi dari modal sendiri badan usaha sebesar $30 \%$ dari total kebutuhan pendanaan. Oleh karena itu, pinjaman sebaiknya dimulai pada tahun 2018 untuk menghindari risiko bunga.

4. Capital expenditure (capex) yang digunakan ialah jumlah dari kebutuhan pendanaan untuk fisik gedung dan alat-alat kesehatan dengan total sebesar Rp485,69 ditambah dengan bunga yang timbul selama masa konstruksi atau interest during construction (IDC).

5. Operating expenditure (opex) dimulai sebesar $10 \%$ dari capex sebelum IDC dan akan terus naik sebesar $5 \%$ setiap tahunnya.

6. Margin yang diberikan kepada badan usaha pelaksana sebesar $35 \%$ dari total capex dan opex tiap tahun. Pertimbangan tersebut karena pada dasarnya badan usaha pelaksana ialah organisasi sektor privat yang profit oriented. Oleh karena itu, margin sebesar $35 \%$ dianggap akan mampu menarik minat investor atau badan usaha untuk berinvestasi.

7. Tarif Pajak Penghasilan Badan ditentukan sebesar $25 \%$ yang merupakan tarif Pajak Penghasilan Badan sesuai dengan peraturan perpajakan di Indonesia.

8. Asumsi-asumsi ekonomi dan keuangan mengacu pada Studi Kelayakan Perluasan bangunan dan fasilitas RSUD Wates Kabupaten Kulon Progo yang telah disusun oleh Pemerintah Kabupaten Kulon Progo.

9. Biaya lain-lain diasumsikan Rp0 (nol rupiah).

Berdasarkan asumsi-asumsi di atas, maka dapat dilakukan simulasi pembayaran ketersediaan layanan yang akan dibayarkan oleh Pemerintah Kabupaten Kulon Progo setiap tahun selama masa konsesi KPBU dengan skema pembayaran ketersediaan layanan. Pertama yang dilakukan yaitu dengan menghitung total capex ditambah IDC.

Tabel 3 Total Capex ditambah IDC (dalam milyar rupiah)

\begin{tabular}{cc}
\hline CAPEX & Rp \\
\hline Modal Sendiri (30\% dari Total Investasi) & 145,71 \\
\hline
\end{tabular}




\begin{tabular}{lr}
\hline Modal Pinjaman (70\% dari total Investasi) & 339,98 \\
\hline Capex sebelum IDC (1) & $\mathbf{4 8 5 , 6 9}$ \\
\hline IDC: & 35,19 \\
\hline - Tahun 1 (2018) & $\mathbf{5 2 0 , 8 8}$ \\
\hline Capex + IDC &
\end{tabular}

Tabel 3 menunjukkan bahwa bunga yang timbul dalam masa konstruksi aset yang akan dikapitalisasi ke dalam capex yaitu sebesar Rp35,19 milyar. Dengan demikian, total capex setelah ditambah dengan IDC ialah sebesar Rp520,88 milyar. Setelah capex ditambah IDC ditentukan, maka selanjutnya dapat dilakukan perhitungan pembayaran ketersediaan layanan.

Tabel 4 Perhitungan Pembayaran ketersediaan layanan (dalam milyar rupiah)

\begin{tabular}{rrrrr} 
Tahun & \multicolumn{1}{c}{ Capex } & \multicolumn{1}{l}{ Opex } & Margin & \multicolumn{1}{l}{ AP } \\
\hline 2019 & 52,09 & 48,57 & 35,23 & 135,89 \\
\hline 2020 & 52,09 & 51,00 & 51,00 & 139,17 \\
\hline 2021 & 52,09 & 53,55 & 53,55 & 142,61 \\
\hline 2022 & 52,09 & 56,22 & 56,22 & 146,22 \\
\hline 2023 & 52,09 & 59,04 & 59,04 & 150,02 \\
\hline 2024 & 52,09 & 61,99 & 62,98 & 154,00 \\
\hline 2025 & 52,09 & 65,09 & 65,09 & 158,19 \\
\hline 2026 & 52,09 & 68,34 & 68,34 & 162,58 \\
\hline 2027 & 52,09 & 71,76 & 71,76 & 167,19 \\
\hline 2028 & 52,09 & 75,35 & 75,35 & 172,04 \\
\hline Jumlah & $\mathbf{5 2 0 , 8 8}$ & $\mathbf{6 1 0 , 9 0}$ & $\mathbf{3 9 5 , 1 2}$ & $\mathbf{1 . 5 2 7 , 9 0}$ \\
\hline
\end{tabular}

Berdasarkan tabel 4, total pembayaran ketersediaan layanan selama 10 tahun yang harus dibayar oleh Pemerintah Kabupaten Kulon Progo selaku Penanggung Jawab Proyek Kerjasama adalah sebesar Rp1.527,90 milyar.

\section{Analisis Komparatif Alternatif Pendanaan}

Tabel 5 Hasil Analisis Komparatif Alternatif Pendanaan (dalam milyar rupiah)

\section{Penerimaan Umum APBD}

PV Investasi Fisik Gedung 243,02

PV Investasi Alat Kesehatan 184,51

PV Pengorbanan atas Layanan yang Tidak Diberikan 105,58

PV Operating Expenditure 320,28

PV Pengorbanan atas Alokasi Anggaran yang Ditunda 427,52

Total PV Penerimaan Umum APBD (A) $1.280,91$ 


\begin{tabular}{|c|c|}
\hline \multicolumn{2}{|l|}{ Obligasi Daerah } \\
\hline $\begin{array}{l}\text { PV Dana Cadangan Untuk Pembayaran Pokok Obligasi Daerah } \\
\text { dikurangi Bunga }\end{array}$ & 167,83 \\
\hline PV Bunga Obligasi & 249,68 \\
\hline PV Operating Expenditure & 361,69 \\
\hline Total PV Obligasi Daerah (B) & 779,20 \\
\hline \multicolumn{2}{|l|}{ Pembayaran ketersediaan layanan } \\
\hline PV Pembayaran ketersediaan layanan & 918,13 \\
\hline Present Value PPh Badan yang akan diterima & $(67,91)$ \\
\hline Total PV Pembayaran ketersediaan layanan (C) & 850,22 \\
\hline Tingkat Diskonto & $8,32 \%$ \\
\hline Selisih (A) dan (B) & 501,71 \\
\hline Selisih (A) dan (C) & 430,69 \\
\hline Selisih (C) dan (B) & 71.02 \\
\hline
\end{tabular}

Langkah-langkah yang dilakukan dalam analisis ini ialah dengan mengidentifikasi potensi-potensi pengorbanan ekonomi pada masing-masing alternatif pendanaan, kemudian dibandingkan dengan potensi pengorbanan ekonomi jika pembangunan tersebut dilakukan secara tradisional atau menggunakan dana penerimaan umum daerah.

Analsis alternatif pendanaan ini dilakukan dengan pendekatan time value of money. Penggunaan time value of money dalam perbandingan alternatif pendanaan karena pada umumnya nilai uang sekarang lebih berharga dari pada nilai uang di masa mendatang. Seluruh potensi pengorbanan ekonomi harus dipastikan telah diperhitungkan dalam setiap alternatif pendanaan untuk memastikan bahwa perbandingan alternatif pendanaan tersebut apple to apple.

Dalam analisis time value of money tersebut, tingkat diskonto yang digunakan ialah $8,32 \%$. Tingkat diskonto tersebut mengacu pada cost of capital yang dihitung dengan menjumlahkan antara tingkat suku bunga obligasi sebesar $7,17 \%$, social opportunity cost sebesar $1,00 \%$ dan Social Rate of Time Preference sebesar 0,15\%. Social opportunity cost dan Social Rate of Time Preference merupakan pertimbangan yang harus ada dalam organisasi sektor publik karena hal yang menjadi pertimbangan utamanya ialah kualitas layanan yang dapat diterima oleh masyarakat. 


\section{Present Value Penerimaan Umum APBD}

Berdasarkan Tabel 5 tersebut, ketika pembangunan infrastruktur menggunakan dana dari penerimaan umum APBD, maka terdapat total present value potensi pengorbanan ekonomi sebesar Rp1.280,91 milyar. Nilai tersebut merupakan hasil penjumlahan dari present value investasi fisik gedung, present value investasi alat kesehatan, present value pengorbanan ekonomi atas layanan yang tidak diberikan, present value operating expenditure dan present value pengorbanan ekonomi atas alokasi anggaran yang ditunda.

Present value investasi fisik gedung sebesar Rp243,02 milyar merupakan nilai sekarang dari seluruh alokasi dana yang akan dikeluarkan untuk membangun fisik gedung RSUD Wates. Dalam Studi Kelayakan Perluasan Gedung dan Fasilitas RSUD Wates Kabupaten Kulon Progo, penyediaan dana untuk kebutuhan fisik gedung dilakukan secara bertahap selama 3 tahun yaitu tahun 2017 hingga tahun 2019. Oleh karena itu, dana yang dikeluarkan pada tahun kedua dan ketiga di-present value-kan.

Present value investasi alat kesehatan sebesar Rp184,50 milyar merupakan nilai sekarang dari seluruh alokasi dana yang akan dikeluarkan untuk pengadaan alat-alat kesehatan RSUD Wates. Dalam Studi Kelayakan Perluasan Gedung dan Fasilitas RSUD Wates Kabupaten Kulon Progo, penyediaan dana untuk pengadaan alat-alat kesehatan dilakukan secara bertahap selama 2 tahun yaitu tahun 2018 dan tahun 2019. Oleh karena itu, dana yang dikeluarkan pada tahun tersebut di-present value-kan.

Present value pengorbanan ekonomi atas layanan yang tidak diberikan sebesar Rp105,58 milyar merupakan nilai sekarang dari potensi atas layanan jasa yang ditaksir akan diperoleh jika perluasan bangunan dan fasilitas RSUD Wates dapat beroperasi pada tahun 2019. Layanan kesehatan yang tidak diberikan dihitung sebagai salah satu pengorbanan ekonomi yang harus ditanggung, karena jika menggunakan skema obligasi daerah atau pembayaran ketersediaan layanan, maka pada tahun 2019 perluasan bangunan dan fasilitas RSUD Wates mulai beroperasi dengan baik dan ditaksir dapat memberikan jasa layanan sebesar Rp123,84 milyar. Jasa layanan tersebut diperoleh dari proyeksi 
pendapatan RSUD Wates tahun 2019 dalam Studi Kelayakan Perluasan Bangunan dan Fasilitas RSUD Wates Kabupaten Kulon Progo.

Present value opex sebesar Rp320,28 milyar merupakan nilai sekarang dari biaya operasi yang ditaksir akan keluar pada saat hasil perluasan bangunan dan fasilitas RSUD Wates mulai beroperasi. Nilai dari opex ditentukan sama dengan nilai opex dari ketiga alternatif pendanaan. Infrastruktur tersebut mulai beroperasi pada tahun keempat, sehingga opex yang diperhitungkan ialah opex yang timbul sejak tahun keempat.

Present value pengorbanan ekonomi atas alokasi anggaran yang ditunda sebesar Rp427,52 milyar merupakan nilai sekarang dari potensi alokasi anggaran yang ditunda untuk kebutuhan lainnya karena harus dialokasi pada proyek perluasan bangunan dan fasilitas RSUD Wates Kabupaten Kulon Progo. Pengorbanan ekonomi tersebut seharusnya dapat dialokasikan pada kebutuhan dan pembangunan lainnya jika saja Pemerintah Kabupaten Kulon Progo menggunakan alternatif pendanaan obligasi daerah atau pembayaran ketersediaan layanan dalam mendanai proyek perluasan bangunan dan fasilitas RSUD Wates Kabupaten Kulon Progo. Nilai pengorbanan ekonomi tersebut ialah sesuai dengan nilai kebutuhan investasi untuk fisik gedung dan alat kesehatan proyek perluasan bangunan dan fasilitas RSUD Wates Kabupaten Kulon Progo.

\section{Present Value Obligasi Daerah}

Pada Tabel 5 menunjukkan bahwa skema pendanaan obligasi daerah terdapat total present value sebesar $\mathrm{Rp} 779,20$ milyar. Nilai tersebut merupakan hasil penjumlahan dari present value dana cadangan untuk pembayaran pokok obligasi daerah dikurangi bunga, present value bunga obligasi, dan present value opex. Dengan pendanaan menggunakan obligasi daerah, maka konstruksi diperkirakan hanya 2 tahun, karena penyediaan dana dengan obligasi daerah diyakini akan lebih cepat satu tahun dibandingkan dengan menggunakan dana dari penerimaan umum daerah. 
Present value dana cadangan untuk pembayaran pokok obligasi daerah dikurangi bunga sebesar Rp167,83 milyar merupakan nilai sekarang dari dana yang dicadangkan mulai tahun ketiga hingga tahun kesepuluh, dikurangi dengan present value atas bunga yang timbul dari dana cadangan tersebut. Dana cadangan tersebut disimpan dalam bentuk deposito dengan tujuan untuk mengantisipasi pembayaran pokok obligasi daerah pada saat jatuh tempo di tahun kesepuluh atau pada tahun 2026. Pembentukan dana cadangan dimulai pada saat infrastruktur tersebut mulai beroperasi yaitu pada tahun 2019. Oleh karena itu, dana candangan akan dibentuk selama 8 tahun. Dana yang dicadangkan setiap tahun sebesar Rp47,31 milyar. Angka tersebut diperoleh dari perhitungan nilai anuitas majemuk dengan anuitas yaitu pokok obligasi daerah sebesar Rp485,69 milyar dan tingkat suku bunga sesuai suku bunga deposito yaitu $7,02 \%$.

Present value bunga obligasi sebesar Rp249,68 milyar merupakan akumulasi nilai sekarang dari bunga obligasi. Sebagaimana telah dijelaskan sebelumnya bahwa bunga obligasi sebesar $7,17 \%$ dari pokok obligasi dan akan dibayarkan setiap tahunnya.

Present value opex sebesar Rp361,69 milyar merupakan nilai sekarang dari biaya operasi yang ditaksir akan keluar pada saat hasil perluasan bangunan dan fasilitas RSUD Wates mulai beroperasi. Nilai dari opex ditentukan sama dengan nilai opex dari ketiga alternatif pendanaan. Sebagaimana telah dijelaskan sebelumnya bahwa dengan skema obligasi daerah, maka masa konstruksi hanya 2 tahun, maka pada tahun 2019 infrastruktur tersebut muai beroperasi. Oleh karena itu, opex akan mulai diperhitungkan pada tahun ketiga atau tahun infrastruktur mulai beroperasi.

\section{Present Value Pembayaran ketersediaan layanan}

Pada Tabel 5 juga dapat dilihat bahwa present value potensi pengorbanan ekonomi yang akan ditanggung ketika menggunakan skema pendanaan pembayaran ketersediaan layanan yaitu sebesar Rp850,22 milyar. Angka tersebut merupakan total present value 
pembayaran ketersediaan layanan dikurangi dengan present value PPh Badan yang akan diterima.

Present value pembayaran ketersediaan layanan sebesar Rp918,13 milyar merupakan akumulasi nilai sekarang dari pembayaran ketersediaan layanan yang akan dibayarkan oleh Pemerintah Kabupaten Kulon Progo selaku PJPK setiap tahunnya. Sementara itu, present value PPh Badan yang diterima sebesar Rp67,91 milyar merupakan pajak yang akan dibayarkan oleh badan usaha pelaksana atas aliran kas bersih yang diterima setelah dikurangi dengan pembiayaan. Present value PPh Badan yang diterima akan mengurangi total biaya yang ditanggung Pemerintah Kulon Progo karena PPh Badan ini merupakan salah satu aliran kas masuk ke Pemerintah Kabupaten Kulon Progo sebagai satu kesatuan entitas dengan seluruh tingkat pemerintahan di Indonesia.

Setelah mengetahui total pengorbanan ekonomi yang ditanggung oleh Pemerintah Kabupaten Kulon Progo pada masing-masing alternatif pendanaan tersebut, maka selanjutnya dapat ditentukan alternatif pendanaan mana yang membutuhkan pengorbanan ekonomi lebih rendah untuk mengetahui alternatif pendanaan yang paling efisien. Selisih pengorbanan ekonomi yang dikeluarkan oleh Pemerintah Kabupaten Kulon Progo pada masing-masing alternatif tersebut dapat dilihat pada Grafik 1.

Berdasarkan Grafik 1, dapat dilihat bahwa skema pendanaan obligasi daerah dan pembayaran ketersediaan layanan membutuhkan pengorbanan ekonomi lebih rendah dibanding ketika menggunakan pendanaan dari penerimaan umum daerah. Selain itu, skema pendanaan obligasi daerah juga membutuhkan pengorbanan ekonomi lebih rendah dibanding ketika menggunakan skema pembayaran ketersediaan layanan. 


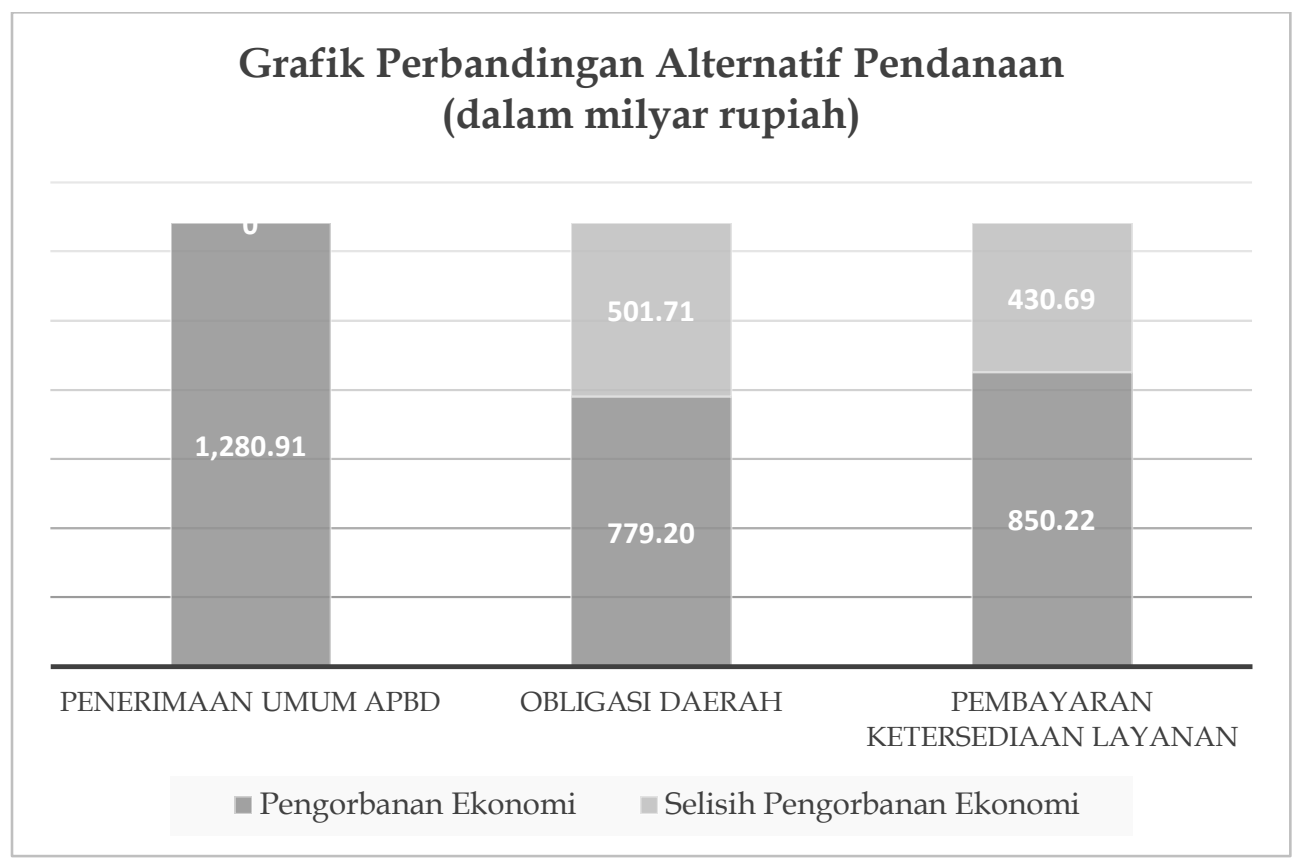

Grafik 1 Ringkasan Perbandingan Alternatif Pendanaan

Selisih pengorbanan ekonomi dari pendanaan penerimaan umum daerah dengan obligasi daerah yaitu sebesar Rp501,71 milyar. Selisih pengorbanan ekonomi antara pendanaan dari penerimaan umum daerah dengan pembayaran ketersediaan layanan yaitu sebesar Rp430,69 milyar. Sedangkan selisih antara alternatif pendanaan obligasi daerah dengan pembayaran ketersediaan layanan yaitu sebesar Rp71,02 milyar. Dengan demikian, apabila Pemerintah Kabupaten Kulon Progo menggunakan skema pendanaan obligasi daerah dalam perluasan bangunan dan fasilitas RSUD Wates Kabupaten Kulon Progo, maka dapat melakukan efisiensi dana sebesar Rp501,71 milyar dibanding ketika menggunakan sumber pendanaan dari penerimaan umum daerah dan dapat melakukan efisiensi dana sebesar Rp71,02 milyar dibanding ketika menggunakan alternatif pendanaan pembayaran ketersediaan layanan.

\section{SIMPULAN}

Penelitian ini bertujuan untuk mengetahui alternatif pendanaan yang paling efisien antara obligasi daerah dan pembayaran ketersediaan layanan dibandingkan dengan pendanaan dari penerimaan umum daerah. Penelitian ini mengacu pada proyek 
pengembangan RSUD Wates Kabupaten Kulon Progo. Berdasarkan pembahasan yang telah dijelaskan, maka hasil penelitian ini dapat disimpulkan sebagai berikut.

1. Alternatif pendanaan yang paling efisien adalah alternatif pendanaan obligasi daerah jika dibandingkan dengan pembayaran ketersediaan layanan dan pendanaan dari penerimaan umum daerah.

2. Apabila Pemerintah Kabupaten Kulon Progo memilih alternatif pendanaan skema obligasi daerah dengan tenor 10 tahun dan bunga 7,17\%, maka dapat melakukan efisiensi dana sebesar Rp501,71 milyar dibanding ketika menggunakan sumber pendanaan dari penerimaan umum daerah.

3. Apabila Pemerintah Kabupaten Kulon Progo memilih alternatif pendanaan skema pembayaran ketersediaan layanan dengan masa konsesi 10 tahun dan margin 35\% dari total capex dan opex tiap tahun, maka dapat melakukan efisiensi dana sebesar Rp430,69 milyar dibanding ketika menggunakan sumber pendanaan dari penerimaan umum daerah.

\section{DAFTAR PUSTAKA}

Ambarwati, D. I. (2016). Penerbitan Obligasi Daerah Dalam Menunjang Ketahanan Ekonomi Daerah: Studi pada Pemerintah Provinsi Sulawesi Selatan. Yogyakarta: Universitas Gadjah Mada.

Angggaran Pendapatan Dan Belanja Daerah Kabupaten Kulon Progo Tahun Anggaran 2017.

Bank Indonesia. (2016). http://www.bi.go.id/id/perbankan/suku-bunga-dasar/Default.aspx

Darmadji, T., \& Fakhruddin. (2006). Pasar Modal di Indonesia Pendekatan Tanya Jawab. Jakarta: Salemba Empat.

Daroedono. (2004). Pengembangan Lembaga Keuangan dan Investasi Infrastruktur. Info Kajian Bappenas.

Dewi, O., \& Kaluge, D. (2011, Oktober). Analisis Peluang Penerbitan Obligasi Daerah Sebagai Alternatif Pembiayaan Daerah. Jurnal of Indonesia Applied Economics, Vol 5(2), 157-171.

DJPK. (2007). Direktorat Jenderal Perimbangan Keuangan, Departemen Keuangan Republik Indonesia. Panduan Penerbitan Obligasi Daerah. Jakarta.

Djunedi, P. (2008). Implementasi Public Private Partnership dan Dampaknya ke APBN. Direktorat Jenderal Anggaran. 
Elmi, B. (2005). Analisa Obligasi Daerah Untuk Membiayai Pembangunan Daerah (Municipal Bond): Kasus Pemerintah Daerah Provinsi Jawa Barat. Kajian Ekonomi dan Keuangan.

Esfahani, H. S., \& Ramı'rez, M. T. (2003). Institutions, infrastructure, and economic growth. Journal of Development Economics , 443-477.

Fatimah, D. S. (2011). Pinjaman Daerah dan Public Private Partnership Sebagai Alternatif Pembiayaan Pembangunan Bandar Udara Perintis Di Kabupaten Labuhanbatu. Yogyakarta: Universitas Gadjah Mada.

Grout, P. (2005). Value For Money Measurements in Public Private Partnerships. European Investment Bank (EIB), 33-56.

Halim, A. (2014). Manajemen Keuangan Sektor Publik: Problematika Penerimaan dan Pengeluaran Pemerintah (Anggaran Pendapatan dan Belanja Negara/Daerah). Jakarta: Salemba Empat.

Inayati, N. I., \& Setiawan, D. (2017). Fenomena Flypaper Effect pada Belanja Daerah Kabupaten/Kota di Indonesia. Jurnal Ekonomi dan Keuangan, 220-239.

Infovesta. 2017. Pilihan Investasi Di Tahun 2017. 25 Februari 2017. Diakses dari https://www.infovesta.com/index/article/articleread;jsessionid=E1357E039E6015F33 6991AC7C65040A9.NGXA/ff3babe7-b0a1-4243-9320-8dc14e3 45a46 pada tanggal 15 Agustus 2017.

Kontan. (2016). Bunga Deposito Berpeluang Turun Hingga Akhir Tahun. Diakses dari http://m.kontan.co.id/news/bunga-deposito-berpeluang-turun-hingga-akhir-tahun pada tanggal 20 Agustus 2017.

Kurniawan, E. S., Pudjianto, B., \& Wicaksono, Y. I. (2009). Analisis Potensi Penerapan Kerjasama Pemerintah Swasta (KPS) Dalam Pengembangan Infrastruktur Transportasi di Perkotaan. Jurnal Teknik, Vol. 30(No. 3), 147-155.

Kusumadewi, D. A., \& Rahman, A. (2007). Flypaper Effect pada Dana Alokasi Umum (DAU) dan Pendapatan Asli Daerah (PAD) Terhadap Belanja Daerah pada Kabupaten/Kota di Indonesia. Jurnal Akuntansi dan Auditing Indonesia (JAAl), 67-80.

Laporan Keuangan Pemerintah Daerah Kabupaten Kulon Progo Tahun Anggaran 2013.

Laporan Keuangan Pemerintah Daerah Kabupaten Kulon Progo Tahun Anggaran 2014.

Laporan Keuangan Pemerintah Daerah Kabupaten Kulon Progo Tahun Anggaran 2015.

Laporan Keuangan Pemerintah Daerah Kabupaten Kulon Progo Tahun Anggaran 2016.

Laporan Akhir Kajian Awal Pra Studi Kelayakan KPBU RSUD Krian Kabupaten Sidoarjo Tahun 2016.

Masitoh, H. (2014, Januari). Public Private Partnership (PPP) Pengelolaan Aset Daerah: Studi Deskriptif tentang Kemitraan antara Perusahaan Daerah Pasar Surya (PDPS) Surabaya dengan PT Arwinto Intan Wijaya (AIW) dalam Pembangunan dan Pengembangan Darmo Trade Centre (DTC) Surabaya. Kebijakan dan Manajemen Publik, Vol 2(1).

Noor, H. F. (2009). Investasi: Pengelolaan Keuangan Bisnis dan Pengembangan Ekonomi Masyarakat. Jakarta: Indeks.

Palei, T. (2015). Assessing The Impact of Infrastructure on Economic Growth and Global Competitiveness. Procedia Economics and Finance 23, hal. 168-175. 
Peraturan Menteri Keuangan Nomor 111/PMK.07 Tahun 2012 tentang Tata Cara Penerbitan dan Pertanggungjawaban Obligasi Daerah.

Peraturan Pemerintah Nomor 30 Tahun 2011 tentang Pinjaman Daerah.

Peraturan Menteri Keuangan Nomor 180/PMK.07 Tahun 2015 tentang Perubahan atas Peraturan Menteri Keuangan Nomor 111/PMK.07 Tahun 2012 tentang Tata Cara Penerbitan dan Pertanggungjawaban Obligasi Daerah.

Peraturan Menteri Perencanaan Pembangunan Nasional atau Kepala Badan Perencanaan Pembangunan Nasional Nomot 4 Tahun 2015 tentang Tata Cara Pelaksanaan Kerjasama Pemerintah Dengan Badan Usaha Dalam Penyediaan Infrastruktur.

Peraturan Pemerintah Nomor 38 Tahun 2015 tentang Kerjasama Pemerintah dengan Badan Usaha dalam Penyediaan Infrastruktur.

Peraturan Menteri Dalam Negeri Nomor 96 Tahun 2016 tentang Pembayaran Ketersediaan Layanan dalam Rangka Kerjasama Pemerintah Daerah dengan Badan Usaha dalam Penyediaan Infrastruktur di Daerah.

PT Sarana Multi Infrastruktur. 2017. Katalis Untuk Infrastruktur Indonesia Yang Lebih Baik. Diakses dari https://www.ptsmi.co.id/id/tentang-kami/tentang-pt-smi/ pada tanggal 28 Mei 2017.

Purnomo, B. S. (2015). Obligasi Daerah: Alternatif Investasi Bagi Masyarakat dan Sumber Pendanaan Bagi Pemerintah Daerah. Bandung: Alfabeta.

Sahoo, P., \& Dash, R. K. (2009). Infrastructure Development and Economic Growth in India. Journal of the Asia Pacific Economy, 14, 351-365.

Sharma, D., \& Cui, Q. (2012). Design of Concession and Annual Payments for Availability Payment Public Private Partnership (PPP) Projects. Construction Research Congress 2012.

Sitorus, T. (2015). Pasar Obligasi Indonesia: Teori dan Praktik (Edisi 1). Jakarta: Raja Grafindo Persada.

Surachman, E. N., \& Setiawan, H. (2016). Municipal Bonds as The Financing Strategy for Urban Infrastructure: Case Study of Jakarta MRT. Jurnal Keuangan dan Perbankan, 369-381.

Tukuboya, M. W., Nurjaman, H. N., \& Suryani, F. (2018). Public Private Partnership pada Konservasi dan Pembangunan Infrastruktur Pengaman Pantai; Studi Kasus Bali. Ikraith Teknologi, 32-40.

Undang-Undang Nomor 23 Tahun 2014 tentang Pemerintah Daerah. 